
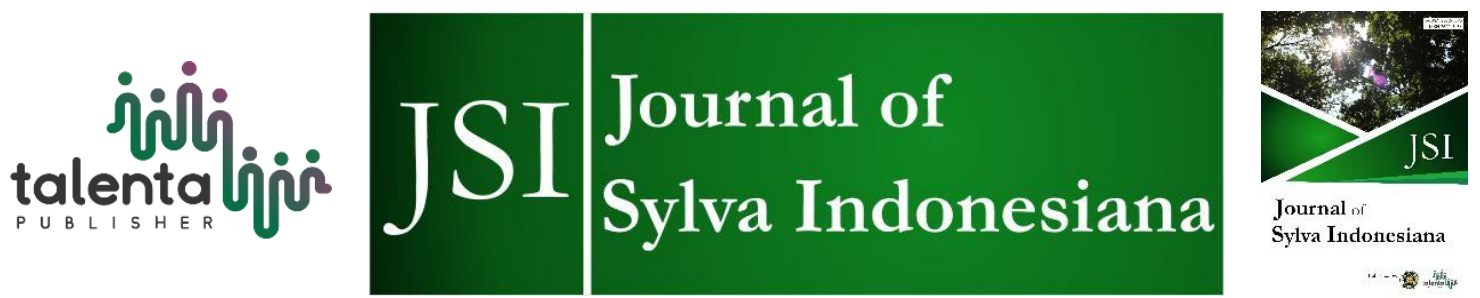

\title{
The Opportunity of Understorey Species to Absorb Secondary Metabolites in the Soil (Case Study in IUPHHK- Industrial Plantation Forests PT. Toba Pulp Lestari, Tbk)
}

\author{
Simon H. Sidabukke ${ }^{1 *)}$, Ternala Alexander Barus ${ }^{2}$, Budi Utomo $^{3}$, Delvian $^{3}$, \\ Mona Fhitri Srena ${ }^{3}$ \\ ${ }^{1}$ PhD Student at Management of Natural Resources and the Environment, Graduated School, Universitas \\ Sumatera Utara, Medan, Indonesia \\ ${ }^{2}$ Faculty of Mathematics and Natural Sciences, Universitas Sumatera Utara, Medan, Indonesia \\ ${ }^{3}$ Faculty of Forestry, Universitas Sumatera Utara, Medan, Indonesia
}

\begin{abstract}
PT. Toba Pulp Lestari, Tbk is one of the industrial forestry companies with Eucalyptus as the main species. This research was conducted in a concession area located in Aek Nauli Plantation, Simalungun Regency, North Sumatra with an area of 22,533 Ha. The sample of this research is understorey species (height: 1.5 meters) under Eucalyptus stand in cycles 2, 3, 4 and 5 planted in 2015. To find out the composition of plant species, vegetation analysis was conducted initially by making minimum species-area curves to determine the number of plots. The placement of the sample starts with randomly distributed on plotted paths. The number of plots in each cycle is as many as 32 plots, 32 plots, 32 plots, 4 plots by 256 plots and 5 plots for 32 plots. The results of soil analysis found that secondary metabolic in eucalyptus soil classified into terpenoid which located at a distance of $50 \mathrm{~cm}$ (flat) and $100 \mathrm{~cm}$ (flat) from the tree at 2 years old Eucalyptus stand. The terpenoids also distributed in distance of $50 \mathrm{~cm}$ from trees with flat topography on 4 years old Eucalyptus stand. For 6 years old Eucalyptus stand, terpenoid distributed on 150 $\mathrm{cm}$ from a tree and there was also a saponin within $150 \mathrm{~cm}$ from a tree with sloping topography. If the dominant undergrowth grows were Strong and Senduduk, the secondary metabolism in the soil will be absorbed by this species.
\end{abstract}

Keyword: Secondary Metabolites, Toba PulpLestari, Understory Vegetation

Received 26 September 2019 | Revised 18 October 2019| Accepted 07 February 2020

\section{Introduction}

The Development of Industrial Plantation Forests (IPF) has been developed in Indonesia since 1984 to reforest the less productive's area, preserve natural forests and to fulfill sustainable raw materials for forest product industries needs. To support the success of IPF development, the

\footnotetext{
*Corresponding author at: Management of Natural Resources and the Environment, Graduated School, Universitas Sumatera Utara, Medan 20155, Indonesia

E-mail address: sidabukke@yahoo.com
}

Copyright (c) 2020 Published by Talenta Publisher 
soil as a plant growth media must be maintained and increased so the forest productivity will be sustainable. The efforts to increase forest potency should be supported by integrative information on soil properties, such as morphology, soil physical properties, chemical, and biological properties and plant growth.

Eucalyptus is one targeted species on IPF which is designated as fiber wood. The criteria for species selected for plantations that will produce pulp are fast-growing, high-productivity, shortcycle species, and the chemical and physical wood properties should be meet with pulp industry raw material requirements [1]. Eucalyptus belongs to Myrtaceae family that grows and distributed from Australia, New Zealand, Papua New Guinea, Philippines, Southern Pacific Island to Eastern Indonesia (Timor Island, Irian Jaya, Seram Island, and Sulawesi). In general, eucalyptus trees are round, straight, not buttressed and have few branches, bush-shaped to treeshaped. The height varies from a few meters to 100 meters. Eucalyptus leaves are generally in lancet to ovate, the tips are slightly hooked, the leaves are $10-15 \mathrm{~cm}$ long, $1.5-5 \mathrm{~cm}$ wide. Characteristics of soils suitable for Eucalyptus plants are soils that have well drainage properties rather obstructed to rather quickly. The texture of clay, dust, clay, sand, or a combination of them. Effective depth: > 50, CEC: > 5, pH: $4.5-8, \mathrm{~N}:>0.1 \%, \mathrm{P}:>10$, and $\mathrm{K}:>10$ [2].

Eucalyptus is a type of plant that contains secondary metabolites, namely allelopathy. The allelopathic secondary metabolite of the individual plant will produce chemicals that can inhibit other plant growth on surrounding these plants. Secondary metabolites that are owned by plants are not only to inhibit the growth of other plant species, but also protect these plants from various predatory organisms, both insect microorganisms, and herbivores [3].

Allelopathic compounds generally found in the form of phenolic acids, koumarat, terpenoids, flavonoids, and scopulaten (photosynthesis inhibitors). Most of the allelopathic compounds produced through root exudates are toxic phenolic acids. The process can occur in soils through a variety of ways, such as exudation or excretion from roots, gas volatility from leaves through stomata, soluble or leaching of fresh leaves through rain or dew, soluble from decomposed litter, and transformation of soil microorganisms. In general, the concentration of allelopathic compound derived from leaching of fresh leaves is much lower than those from decomposed litter. [4].

To ascertain the content of allelopathy found in the soil where Eucalyptus grows and its relation to the ability of plants to absorb the allelopathy content in question, it is necessary to research to determine the ability of undergrowth in the phytoremediation process. Phytoremediation is defined as absorbing pollutants mediated by plants including trees, grasses, and aquatic plants. Leaching can mean the destruction, inactivation or immobilization of pollutants into harmless forms [5]. This study also aims to determine the relationship of undergrowth species with the availability of secondary metabolic compounds (allelopathy) content in soils in plantations of 
Eucalyptus sp. so that it is expected to be a reference in managing environmentally friendly on industrial plantations.

\section{Research Method}

This research was conducted through field and laboratory scale. The field research was conducted in the IPF area of PT Toba Pulp Lestari, Tbk - Aek Nauli Estate, Simalungun Regency, North Sumatra Province, on the Eucalyptus species which 2,3,4 and 5 cycles and the 5th cycle of the planting year 2015. Soil chemical analysis is carried out in the Chemistry Department, Faculty of Mathematics and Natural Sciences, University of Sumatera Utara.

The materials used in the study included: a 2015 IPF planting map work scale of 1: 20,000, an in-depth IPF scale 1: 100,000 land map, a 1: 100,000 HPH work area map and a 1: 250,000 scale geological map obtained from PT Toba Pulp Lestari, Tbk and soil samples taken from Eucalyptus growing places in each cycle. The tools used in the study include compass, meter, ground drill, field vise/knife, markers and cardboard, camera, checklist, and label.

The research procedure consists of:

1. Map preparation. Prepare maps of work areas and maps of plants that have been overlaid with plot sampling locations. Data collection in the field, using vegetation analysis techniques in the form of a combination of paths and checkered lines.

2. The preparation phase begins with field orientation activities, especially in the Eucalyptus block of plants in 2015 which have entered the second cycle, the third cycle, the fourth cycle and the fifth cycle (span of one cycle, which is 5 Years).

3. Eucalyptus plants in each cycle are placed in $2 \times 2$-meter plots, the amount of which is based on the calculation of the minimum species-area curve. Obtained in the second cycle of 32 plots, the third cycle of 32 plots, the fourth cycle of 256 plots and the fifth cycle of 32 plots.

4. Soil sampling is carried out for testing the analysis of chemical compounds of secondary metabolites which are then analyzed in the Laboratory of the Faculty of Mathematics and Natural Sciences, USU. Preparation of soil samples conducted by drying the soil (aerated) to dry, mashed then mixing it with chemicals to ensure the content of secondary metabolites.

5. Testing soil samples to determine the availability of secondary metabolites of chemical compounds in the soil. Tests carried out in the laboratory in the form of qualitative phytochemical tests for Alkaloids with tests (Maeyer, Dragendrof, and Bouncardat), 
Terpenoids with tests (Salkowsky, $\mathrm{CaSO}_{4} 1 \%$ in $10 \% \mathrm{H}_{2} \mathrm{SO}_{4}$, Saponins with $96 \%$ Alcohol $+\mathrm{H}_{2} \mathrm{Cl}_{2} \mathrm{~N}$ test.

6. From each plot measuring $2 \mathrm{~m} \times 2 \mathrm{~m}$, records were recorded for each undergrowth species (plant height $<1.5 \mathrm{~m}$ ).

7. Next is the calculation of plant important value index (IVI) under the stand compiler under the Eucalyptus tree [6]

$$
I N P=R D+R F
$$

where: IVI = Important Value Index (INP)

$\mathrm{KR} \quad=$ Relative Density

FR = Relative Frequency

\section{Result and Discussion}

The results on vegetation analysis in each cycle and the top five understorey species with the highest INP values in each cycle are presented in Table 1.

Table 1 Types of understorey with the five largest INP values in each cycle

\begin{tabular}{cclc}
\hline No. & Cycle & \multicolumn{1}{c}{ Types of understorey } & IVI (\%) \\
\hline 1 & & Sintrong (Crassocephalum crepidioides Benth.) & 62.95 \\
2 & & Senduduk (Melastoma malabathricum L) & 54.30 \\
3 & \multirow{2}{*}{ Second cycle } & Sirih hutan (Piper betle L.) & 10.69 \\
4 & & Lengkuas Hutan (Alpinia Malaccensis (Burm. F.) & 6.41 \\
& & Roxb.) & \\
5 & & Duhut baru (Paspalum conjugatum ) & 6.23 \\
\hline 6 & & Senduduk (Melastoma malabathricum L) & 51.33 \\
7 & & Sintrong (Crassocephalum crepidioides Benth.) & 41.70 \\
8 & \multirow{2}{*}{ Third cycle e } & Anti Keong (Tithonia diversifolia) & 16.06 \\
9 & Bunga terong (Solanum torvum Swartz.) & 9.31 \\
10 & & Rumput rotan & 7.67 \\
\hline 11 & & Sapilpil (Dicranopteris linearis (Burm.f.) Underw) & 7.36 \\
12 & & Sintrong (Crassocephalum crepidioides (Benth.) & 45.99 \\
13 & & Paetan (Paspalum conjugatum Berg) & 39.84 \\
14 & Fourth cycle & Senduduk (Melastoma malabathricum L) & 31.04 \\
15 & & Rotan (Calamus sp) & 14.71 \\
16 & & Ratusan (Foeniculum vulgare Miller) & 8.81 \\
17 & & Senduduk (Melastoma malabathricum L) & 64.24 \\
18 & & Sintrong (Crassocephalum crepidioides (Benth.) & 42.61 \\
19 & Fifth cycle & Paetan (Paspalum conjugatum Berg) & 20.65 \\
20 & & Anti keong (Tithonia diversifolia) & 9.73 \\
21 & & Ratusan (Foeniculum vulgare Miller) & 7.44 \\
\hline
\end{tabular}

Based on Table 1, several species that remain present in each cycle were Sintrong (Crassocephalum crepidioides Benth.) S. Moor) and Senduduk (Melastoma malabathricum). 
The chemical compounds of secondary metabolites found in the Eucalyptus soil are the result of chemical processes in Eucalyptus plant litter. This finding also supported by several previous studies, such as the results of research [7] that states that allelopathy (secondary metabolites) on Eucalyptus pelita leaves has the potency to be used as bioherbicides. The allelopathic substances suppress the growth of weed Cyperus bravefolius and Eleusine indica leaves, damaging weeds Asystasia intrusa, Borreia alata, Cyperus bravefolius, and Eleusine indica. The results of the study conducted by [8], stated that Eucalyptus pelita is a family of Myrtaceae that contains secondary metabolites such as tannin, saponin, phenol, and glycose. Allelopathic woody plants include Eucalyptus. According to [9] Eucalyptus sp leaves also contain terpenoid allelochemical compounds that can kill weeds underneath.

This is supported by the results [10] research that shows that soil samples with secondary metabolites found in soil samples without vegetation types such as Sintrong and Senduduk are as follows:

a) Terpenoids in 2-year-old Eucalyptus at a distance of $50 \mathrm{~cm}$ (flat) and $100 \mathrm{~cm}$ (flat) from the tree.

b) Terpenoid in 4-year-old Eucalyptus at a distance of $50 \mathrm{~cm}$ from a tree with a flat topography.

c) Terpenoid in a 6-year-old Eucalyptus at a distance of $150 \mathrm{~cm}$ from the tree, sloping topography and a saponin within $150 \mathrm{~cm}$ from a tree with sloping topography.

The results showed that several understorey species found in eucalyptus stand. Five undergrowth species with that highest INP values are found in each cycle. The results also showed that there were no terpenoid compounds or saponins in the analyzed soil samples.

The assumption is some understorey species that dominate the soil able to absorb secondary metabolites from the soil so that the availability of secondary metabolites in the soil is limited or not available. The results of qualitative phytochemical laboratory tests indicate that the overall content of the secondary metabolite compounds tested has negative results. According to [11], the content of secondary metabolites is absorbed by understorey, especially species that have the potential as hyperaccumulator plants that cause secondary metabolite compounds not present in the soil. [5] added that hyperaccumulator properties are properties that can accumulate certain metal elements with high concentrations in the canopy and can be used for phytoremediation purposes because all plants can absorb metals but in varying amounts. Furthermore [11] states that in some families, plants have several advantages, among others, have a tolerant and hyperaccumulating nature of heavy metals naturally.

Phytoremediation is also defined as absorbing pollutants mediated by plants including trees, grasses, and aquatic plants. Leaching can mean the destruction, inactivation or immobilization 
of pollutants into harmless forms [5]. Several plants from many families have been shown to have hyper tolerant properties, which can accumulate metals with high concentrations in their root and crown tissues so that they are hyperaccumulator. It suggested that plant species that can absorb allelopathy in the soil are thought to have hyperaccumulator properties.

\section{Conclusion}

The presence of Senduduk (Melastoma malabathricum L) under Eucalyptus stand will absorb the secondary metabolites (allelopathy) content produced by Eucalyptus so that its availability in the soil will be reduced. Various plant species that can absorb allelopathy in the soil are suspected also as hyperaccumulator species.

\section{REFERENCES}

[1] N. Mindawati, A. Indrawan, I. Mansur, and O. Rusdiana, "Study on Growth in North Sumatra," Jurnal Penelitian Hutan Tanaman, vol. 7, no. 1, pp. 39- 50. 2010.

[2] FAO, Reconnaissance Land Resource Survey Formats Procedures, Center For Soil Research, Ministry of Agriculture Government of Indonesia United Nations Development Programme and Food Agriculture Organization, Bogor, 1983.

[3] Widuri, S.A. Noorcahyati, and A. Puspanti, "Secondary Metabolite Content in Plants with Anti-Diabetes Efficacy by Ethnic Borneo. Potential for the development of modern medicine. Medicinal Plants from the Forest: Conservation, Cultivation, and Utilization," In Proceeding Seminar Balitek KSDA Balikpapan, December 3, 2014. 2014.

[4] M. Djazuli, "Allelopathy in Some Plantation Plants and Control Techniques and Prospects for Utilization," Indonesian Medicinal dan Aromatic Crops Research Institute, vol. 10, no. 1, pp. 44-50. 2011.

[5] R.L Chaney et al, "Potential Use of Metal Hyperaccumulator," Mining Environ Manag, vol. 3, pp. 9-11. 1995.

[6] Onrizal, C. Kusmana, B.H. Saharjo, I.P. Handayani, and T. Kato, "Vegetation Analysis of Secondary Lowland Tropical Rain Forests in Danau Sentarum National Park, West Kalimantan," Jurnal Biologi, vol. 4, no 6. 2005.

[7] M. Audina, "Potential of Eucalyptus pellita F. Muell Leaf Extraction as Post-Growing Bioherbicide," M.S Thesis, Bogor Agriculture University, Department of Agronomy and Horticulture, Bogor, 2017.

[8] B.A. Ayepola and Adeniyi. "The Bacterial Activity of leaf extract of Eucalyptus camadulensis (Myrtaceae)," Journal of Applied Science Research, vol. 4, no. 11, pp. 1410 - 1413. 2008.

[9] R. Faisal, E.B.M. Siregar, N. Anna. "Weed Inventory of Young Plant Stands of Eucalyptus spp.," Peronema Forestry Science Journal, vol. 2, no. 2, pp. 44-49. 2013.

[10] H.S. Simon, T.A. Barus, B. Utomo, Delvian. M.F Serena. "The Relation of Forest Stands to Availability of Secondary Metabolite Content in the Land (A Case Study on HPIPF. PT. Toba Pulp Lestari, Tbk.," In International Conference on Natural Resources and Technology (ICONART), Grandhika Hotel, March 12, 2019, Medan. 2019.

[11] N. Hidayati, "Phytoremediation and Potential of Hyperaccumulator Plants," Jurnal Hayati ISSN 0854 - 8587, vol. 12, no. 1. 2004. 